\title{
Curcumin exerts its antitumor activity through regulation of miR-7/Skp2/p2I in nasopharyngeal carcinoma cells
}

This article was published in the following Dove Press journal:

OncoTargets and Therapy

2 May 2017

Number of times this article has been viewed

Shaoyan Feng, ,,2,* Yu Wang, ,** Rongkai Zhang, ${ }^{4, *}$ Guangwei Yang, ${ }^{5}$ Zibin Liang, ${ }^{5}$ Zhiwei Wang, ${ }^{3}$ Gehua Zhang'

'Department of Otorhinolaryngology, Head and Neck Surgery, The Third Affiliated Hospital of Sun Yat-Sen University, Guangzhou, ${ }^{2}$ Department of Otolaryngology, Head and Neck Surgery, The Fifth Affiliated Hospital of Sun Yat-Sen University, Zhuhai, ${ }^{3}$ The Cyrus Tang Hematology Center and Collaborative Innovation Center of Hematology, Jiangsu Institute of Hematology, the First Affiliated Hospital, Soochow University, Suzhou, ${ }^{4}$ Department of Orthopaedics,

${ }^{5}$ Department of Radiation Oncology,

The Fifth Affiliated Hospital of Sun

Yat-Sen University, Zhuhai, People's

Republic of China

*These authors contributed equally to this work

Correspondence: Gehua Zhang Department of Otorhinolaryngology, Head and Neck Surgery, The Third Affiliated Hospital of Sun Yat-Sen University, No 600 Tianhe Road, Guangzhou, Guangdong, 510630, People's Republic of China Email gehuazhanggz@।63.com

\section{Zhiwei Wang}

The Cyrus Tang Hematology Center and Collaborative Innovation Center of Hematology, Jiangsu Institute of Hematology, the First Affiliated Hospital, Soochow University, 199 Renai Road, Suzhou, Jiangsu, 215123, People's Republic of China

Email zwang6@bidmc.harvard.edu
Abstract: Curcumin, a natural polyphenol compound, exhibits tumor suppressive activity in a wide spectrum of cancers, including nasopharyngeal carcinoma cells. However, the exact molecular mechanisms governing this tumor suppressive activity remain elusive. Multiple studies have revealed that miRNAs are critically involved in tumorigenesis, indicating that targeting miRNAs could be a therapeutic strategy for treating human cancer. In the current study, we set out to determine whether curcumin regulates miR-7 expression in nasopharyngeal carcinoma cells. We found that curcumin inhibited cell growth, induced apoptosis, retarded cell migration and invasion, and triggered cell cycle arrest in the human nasopharyngeal carcinoma cell lines CNE1 and CNE2. Importantly, we observed that curcumin upregulated the expression of miR-7 and subsequently inhibited Skp2, a direct miR-7 target. Our results identified that upregulation of miR-7 by curcumin could benefit nasopharyngeal carcinoma patients.

Keywords: curcumin, nasopharyngeal cancer, miR-7, Skp2, proliferation

\section{Introduction}

Nasopharyngeal carcinoma (NPC) is a rare form of head and neck cancer with an estimated 86,700 new cases and 50,800 deaths globally in 2012. ${ }^{1}$ However, NPC has relatively high incidence rates in Southeast Asia and South-Eastern China, which could be due to genetic factors, environment, and Epstein Barr virus infection. ${ }^{2}$ Interestingly, consumption of certain foods has been associated with NPC incidence, such as salted fish, hot spices, and preserved foods. In addition, smoking and alcohol use may also contribute to NPC incidence. ${ }^{1}$ Radiotherapy is the primary method of treatment for NPC. Radiotherapy in combination with chemotherapy is an effective treatment for locoregionally advanced NPC, ${ }^{3}$ however, survival benefit failed to be significantly improved irrespective of the chemotherapeutic agent or dosing schedules. ${ }^{4}$ The reasons leading to low survival rate for advanced stage NPC may be related to metastasis and drug resistance.

miRNAs are small non-coding RNA molecules that regulate various cellular processes by binding to complementary target sites in the $3^{\prime}$ untranslated regions of mRNAs, and regulating mRNA degradation or translational repression. ${ }^{5}$ It has been demonstrated that miRNAs are critically involved in tumorigenesis, ${ }^{6}$ where they may play either an oncogenic or tumor suppressive role. Consistent with this, high expression of oncogenic miRNAs and down-regulation of antitumor miRNAs are observed in many cancers. ${ }^{7}$ For example, miR-7 has been considered as a tumor suppressive miRNA in a variety of human malignancies, ${ }^{8,9}$ and down-regulation of 
miR-7 has been observed in a variety of human cancers. ${ }^{10-13}$ Intriguingly, miR-7 was reported to inhibit cell growth, migration, and invasion via direct targeting of PAK1 in thyroid cancer cells. ${ }^{14}$ Similarly, miR-7-5p inhibited melanoma cell proliferation and metastasis through suppressing RelA/NF- $\kappa B .{ }^{15}$ Consistently, miR-7 inhibited colon cancer invasion and proliferation through targeting the expression of FAK. ${ }^{16}$ Zhao et al reported that miR-7 enhanced cytotoxicity of gefitinib through inhibition of EGFR and IGF1R pathways in non-small cell lung cancer (NSCLC). ${ }^{17}$ Moreover, docetaxel inhibited cell proliferation via upregulation of miR-7 expression in NSCLC cells. ${ }^{18}$ Furthermore, mutations within the miR-7 promoter are associated with poor prognosis of lung cancer, ${ }^{10}$ and serum miR-7 levels are a predictive biomarker in esophageal squamous cell carcinoma. ${ }^{19}$ Interestingly, miR-7 was identified as an oncogene in renal cell carcinoma. ${ }^{20}$ Moreover, miR-7 was reported to promote epithelial cell transformation through targeting KLF4. ${ }^{21}$ Therefore, it still remains unclear in which contexts miR-7 may carry out oncogenic or tumor suppressive functions in human cancers.

Curcumin, a natural compound derived from turmeric (Curcuma longa), has been reported to exhibit antitumor activity in both in vitro and in vivo studies. ${ }^{22,23}$ Mechanistically, curcumin has been shown to regulate multiple targets including NF- $\mathrm{KB}$, Akt, Notch, mTOR, and Hh. ${ }^{23-25}$ Recently, a growing body of evidence has implicated curcumin in regulating the expression of multiple miRNAs. ${ }^{26}$ Curcumin regulated miR-138 expression, leading to inhibition of cell proliferation and invasion in human osteosarcoma cells. ${ }^{27}$ Moreover, inhibition of miR-21 was suggested to be important for curcumin-mediated anticancer effects. ${ }^{28} \mathrm{Wu}$ et al found that curcumin induced miR-146a expression, resulting in enhancement of temozolomide cytotoxicity against human glioblastoma. ${ }^{29}$ In NPC, curcumin was shown to exert its anticancer effects through inhibition of miR-125a-5p expression. ${ }^{30}$ In the current study, we explored the mechanism of curcumin-mediated anticancer activity in NPC cells.

\section{Materials and methods \\ Cell culture and reagents}

Human NPC cell lines CNE1 and CNE2 were purchased from American Type Culture Collection (ATCC), Manassas, VA, USA and maintained in Roswell Park Memorial Institute-1640 medium containing 10\% fetal bovine serum with penicillin $(100 \mathrm{U} / \mathrm{mL})$ and streptomycin $(100 \mathrm{U} / \mathrm{mL})$ at $37^{\circ} \mathrm{C}$ with $5 \% \mathrm{CO}_{2}$. Primary antibodies against Skp2, tubulin and the secondary antibodies were purchased from
Santa Cruz Biotechnology Inc. (Dallas, TX, USA). Anti-p21 and anti-p57 antibodies were obtained from Cell Signaling Technology (Danvers, MA, USA). Lipofectamine 2000 was purchased from Invitrogen (Thermo Fisher Scientific, Waltham, MA, USA). MTT (3-(4,5-dimethyl-2-thiazolyl)2,5-diphenyl-2-H-tetrazolium bromide) and curcumin (CAS number 458-37-7, 99.5\% purity) was obtained from SigmaAldrich Co. (St Louis, MO, USA). Cells were treated with $0.1 \%$ dimethyl sulfoxide (DMSO) for control conditions.

\section{Cell viability assay}

NPC cells $\left(5 \times 10^{3}\right)$ were seeded in a 96 -well plate overnight. Cells were treated with indicated concentrations of curcumin for $48 \mathrm{~h}$ and $72 \mathrm{~h}$. At the end of the treatment period, $10 \mu \mathrm{L}$ of the MTT $(5 \mathrm{mg} / \mathrm{mL})$ solution was added to each well and cells were incubated for $4 \mathrm{~h}$ at $37^{\circ} \mathrm{C}$. Then, the supernatant was absorbed and $100 \mu \mathrm{L}$ DMSO was added to dissolve MTT-formazan crystals. The absorption was measured in the microplate at $490 \mathrm{~nm}$.

\section{Cell apoptosis analysis}

The Annexin V-fluorescein isothiocyanate/propidium iodide (FITC/PI) apoptosis detection kit (Biouniqure, Shanghai, China) was used to detect the apoptotic cells. Briefly, NPC cells were incubated in 6-well plates overnight and treated with indicated concentrations of curcumin for $48 \mathrm{~h}$. Cells were harvested, washed with phosphate-buffered saline (PBS), and resuspended in $500 \mu \mathrm{L}$ of binding buffer with $5 \mu \mathrm{L}$ PI and $5 \mu \mathrm{L}$ FITC-conjugated anti-Annexin V antibody. The cells were kept in the dark for $15 \mathrm{~min}$ at room temperature. Apoptosis was measured using a FACScalibur flow cytometer (BD Biosciences, San Jose, CA, USA).

\section{Cell cycle analysis}

NPC cells were seeded in a 6-well plate and incubated overnight. The cells were treated with curcumin and cultured for $48 \mathrm{~h}$, collected, and fixed with ice-cold 70\% (v/v) ethanol and stored at $4^{\circ} \mathrm{C}$ overnight. Fixed cells were washed and resuspended at $1 \times 10^{6}$ cells $/ \mathrm{mL}$ in PBS and incubated with $0.1 \mathrm{mg} / \mathrm{mL}$ RNase A and $50 \mathrm{mg} / \mathrm{mL}$ PI at $37^{\circ} \mathrm{C}$ for 30 min. PI staining was measured with a FACScalibur flow cytometer.

\section{Wound healing assay}

NPC cells were seeded in a 6-well plate and allowed to grow until confluent. Once confluent, cells were scraped off (scratched) in a straight line using a sterile pipette tip. The cells were washed with PBS and treated with curcumin 
for $15 \mathrm{~h}$. The scratched area was photographed at $0 \mathrm{~h}$ and $15 \mathrm{~h}$, respectively.

\section{Transwell invasion assay}

Cell invasive capacity of NPC cells was measured using transwell filter with Matrigel (BD Biosciences). Briefly, NPC cells treated with curcumin were transferred into the upper chamber in $200 \mu \mathrm{L}$ of serum-free medium. An amount of $500 \mu \mathrm{L}$ complete medium was added into each bottom chamber with the same concentration of curcumin. After incubation for $20 \mathrm{~h}$, the cells in the upper chamber were removed, and the invaded cells in the membrane were stained with Wright-Giemsa. The cells were also stained with $4 \mu \mathrm{g} / \mathrm{mL}$ calcein AM in Hanks' buffered saline at $37^{\circ} \mathrm{C}$ for $1 \mathrm{~h}$. The stained cells were photographed and counted (at least six randomly-selected fields) under a microscope.

\section{Western blotting analysis}

NPC cells were harvested, washed with PBS, and lysed. The protein concentrations were determined using BCA Protein Assay kit (Thermo Fisher Scientific). Protein samples were separated by sodium dodecyl sulfate-polyacrylamide gel electrophoresis and then transferred onto a polyvinylidene difluoride membrane. The membranes were incubated with primary antibodies at $4^{\circ} \mathrm{C}$ overnight. After washing three times with tris-buffered saline with Tween ${ }^{\circledR} 20$, the membranes were incubated with secondary antibody at room temperature for $1 \mathrm{~h}$. The protein bands were subsequently detected by enhanced chemiluminescence assay.

\section{MiRNA real-time reverse transcription polymerase chain reaction (RT-PCR)}

RT-PCR was performed to measure the changes in miR-7 expression in NPC cells treated with curcumin. Briefly, 10 ng of total RNA was reverse transcribed into cDNA using TaqMan miRNA hsa-miR-7-specific primers (Applied Biosystems, Thermo Fisher Scientific). Then real-time PCR was conducted by a TaqMan MicroRNA Reverse Transcription Kit (Applied Biosystems, Thermo Fisher Scientific). RNA U6 was determined and used as endogenous control in each sample.

\section{MiR-7 mimics transfection}

NPC cells were transfected with miR-7 mimics (Genepharma, Shanghai, China) or a non-specific control using Lipofectamine RNAiMAX reagent (Invitrogen, Thermo Fisher Scientific) following the manufacturer's protocol. MiR-7 mimics: sense 5'-UGG AAG ACU AGU GAU UUU GUU GU-3'; antisense
5'-AAC AAA AUC ACU AGU CUU CCA UU-3'. After the indicated periods of incubation, the cells were subjected to further analysis as described under the results section.

\section{MiRNA-7 inhibitor transfection}

Cells were seeded in 6-well plates and transfected with antisense miR-7 oligonucleotide (Genepharma) or the nonspecific control, using DharmaFect Transfection Reagent (Dharmacon, Lafayette, CO, USA). MiR-7 inhibitor: 5'-ACA ACA AAA AUC ACU AGU CUU CCA-3'.

\section{Statistical analysis}

All data analyses were conducted using GraphPad Prism 4.0 (GraphPad Software Inc., La Jolla, CA, USA). Statistical comparisons were performed using the Student's $t$-test. Results are expressed as means \pm standard deviation. $P$-values $<0.05$ were considered statistically significant.

\section{Results}

\section{Curcumin inhibited cell proliferation}

To explore whether curcumin could suppress cell proliferation in the NPC cell lines CNE1 and CNE2, cells were treated with increasing concentrations of curcumin, and subsequently cell proliferation was determined using an MTT assay. We found that curcumin significantly inhibited cell proliferation in both NPC cell lines (Figure 1A). Specifically, treatment with $5 \mu \mathrm{M}$ and $10 \mu \mathrm{M}$ of curcumin for $72 \mathrm{~h}$ led to $40 \%$ and $65 \%$ inhibition of cell proliferation in CNE1 cells, respectively (Figure 1A). In addition, treatment with $10 \mu \mathrm{M}$ and $15 \mu \mathrm{M}$ of curcumin for $72 \mathrm{~h}$ led to $55 \%$ and $70 \%$ inhibition of cell proliferation in CNE2 cells, respectively (Figure 1A). Therefore, curcumin inhibited cell proliferation in both NPC cell lines.

\section{Curcumin triggered apoptosis}

In order to determine whether curcumin triggered apoptosis, curcumin-treated NPC cells were stained with Annexin $\mathrm{V}$-FITC/PI. We found that $5 \mu \mathrm{M}$ and $10 \mu \mathrm{M}$ curcumin treatments led to CNE1 cell apoptosis from 9.3\% to $27.8 \%$ and $45.4 \%$, respectively (Figure 1B). Similarly, the percentage of apoptotic cells increased from $14.1 \%$ in the control to $32.8 \%$ and $64.1 \%$ in $10 \mu \mathrm{M}$ and $15 \mu \mathrm{M}$ curcumin-treated CNE2 cells, respectively (Figure 1B). These findings demonstrated that curcumin induced cellular apoptosis, that contributed to the observed inhibition in cell proliferation.

\section{Curcumin induced cell cycle arrest}

In addition to regulation of cellular proliferation by induction of apoptosis, we also assessed if cell cycle arrest was induced by curcumin to inhibit cellular proliferation of NPC cells. 

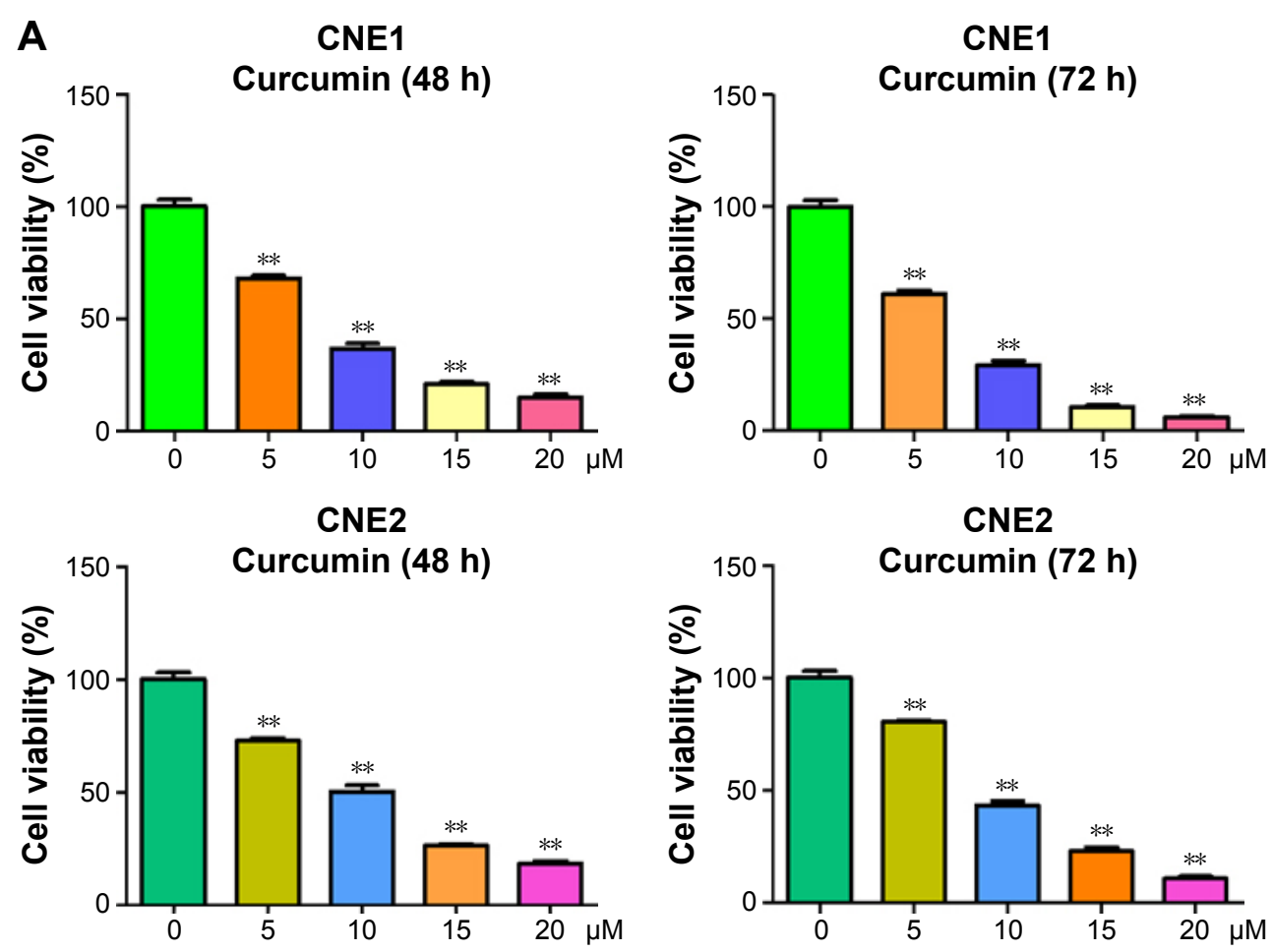

B

CNE1 cell
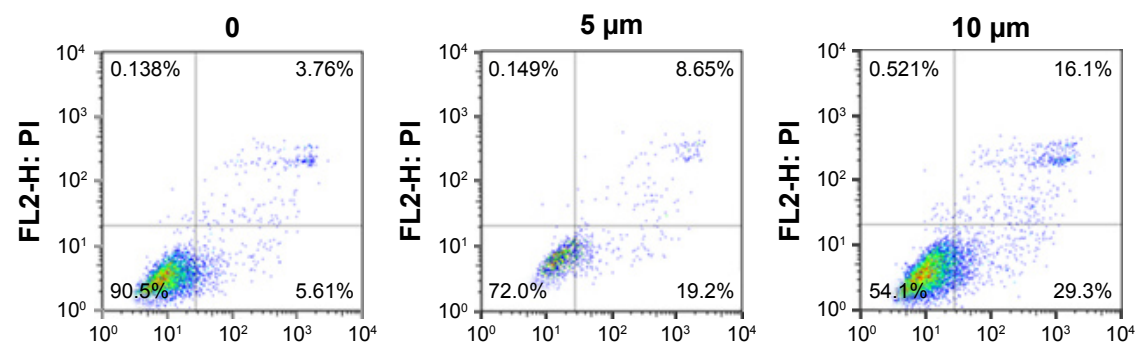

FL1-H: Annexin V-FITC

FL1-H: Annexin V-FITC

FL1-H: Annexin V-FITC

CNE2 cell
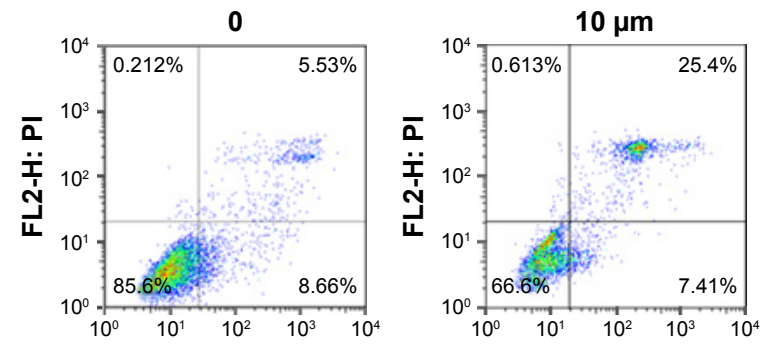

FL1-H: Annexin V-FITC

FL1-H: Annexin V-FITC

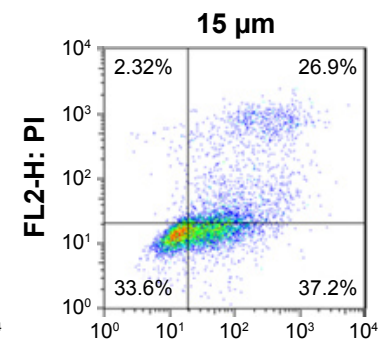

FL1-H: Annexin V-FITC

Figure I Effect of curcumin on NPC cell growth and apoptosis.

Notes: (A) MTT assay following curcumin treatment of NPC cells' growth. $* * P<0.05$, compared to the control (DMSO treatment). (B) NPC cells were stained with Annexin V-FITC/PI and assessed with flow cytometry to determine apoptosis in NPC cells treated with curcumin.

Abbreviations: NPC, nasopharyngeal carcinoma; MTT, (3-(4,5-dimethyl-2-thiazolyl)-2,5-diphenyl-2-H-tetrazolium bromide); DMSO, dimethyl sulfoxide; FITC/PI, fluorescein isothiocyanate/propidium iodide; $\mathrm{FLI}-\mathrm{H}$, fluorescence $\mathrm{I}-\mathrm{H} ; \mathrm{FL} 2-\mathrm{H}$, fluorescence $2-\mathrm{H}$.

To determine whether curcumin regulates cell cycle progression, treated cells were stained with PI to measure DNA content, and assessed for cell cycle analysis. We observed that curcumin treatment induced a $\mathrm{G} 2 / \mathrm{M}$ cell cycle arrest in both NPC cell lines. The G2/M phase fraction was increased from
$7.29 \%$ in control cells to $38.99 \%$ and $51.94 \%$ in $5 \mu \mathrm{M}$ and $10 \mu \mathrm{M}$ curcumin-treated CNE1 cells, respectively (Figure 2). Similar G2/M arrest was identified in curcumin-treated CNE2 cells (Figure 2). These results revealed that curcumin induced cell cycle arrest in NPC cells. 

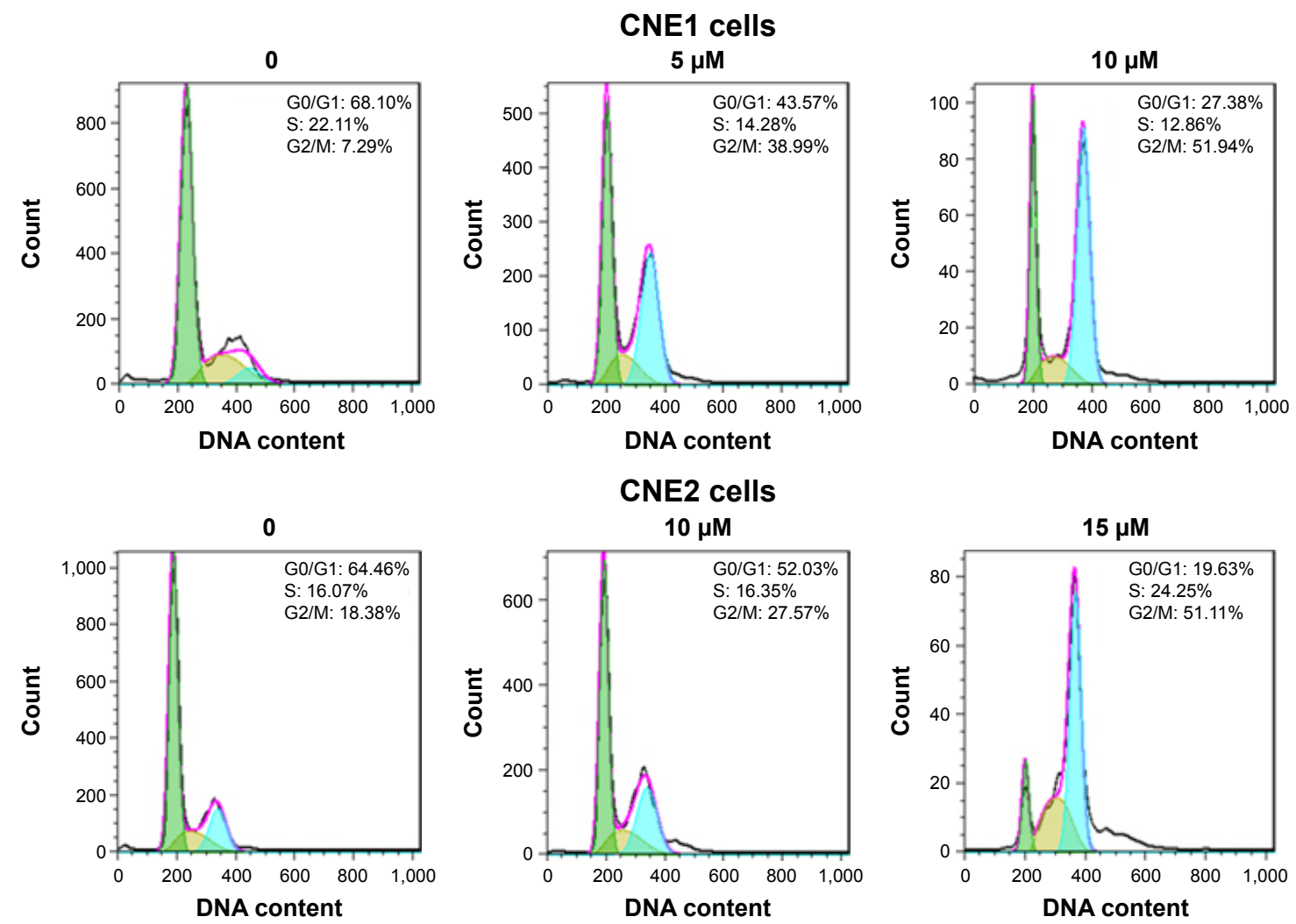

Figure 2 Effect of curcumin on NPC cell cycle.

Notes: NPC cells were stained with PI and assessed with flow cytometry to determine cell cycle profiles of NPC cells after curcumin treatment. Curcumin induced NPC cell cycle arrest at G2/M phase. Green color: G0/GI phase; brown color: S phase; blue color: G2/M phase.

Abbreviations: NPC, nasopharyngeal carcinoma; PI, propidium iodide.

\section{Curcumin retarded cell migration and invasion}

Several studies have reported that curcumin inhibited cell migration and invasion in various types of human cancer cell lines. In order to evaluate whether curcumin could govern cell motility in NPC cells, we utilized wound healing and transwell assays in NPC cells following curcumin treatment. Our wound healing assay results demonstrated that curcumin significantly inhibited cell migration (Figure 3 ). Consistent with inhibition of cell motility by curcumin, transwell assay results demonstrated that curcumin suppressed the invasion of NPC cells into the Matrigel-coated membrane in a dosedependent manner (Figure 4A and B). Our findings suggest that curcumin inhibited both cell migration and invasion in NPC cells.

\section{Curcumin inhibited Skp2 expression}

Skp2, a substrate recognition component of an SCF E3 ubiquitin-protein ligase complex, has been characterized as an oncoprotein during tumorigenesis. ${ }^{31}$ To further explore the molecular mechanism by which curcumin exerts its tumor suppressive function, the expression of Skp2 was measured by Western blotting in NPC cells after curcumin treatment. We found that curcumin down-regulated the expression of Skp2 in both NPC cell lines (Figure 5A and B). Furthermore, two targets of Skp2, p21, and p57, were upregulated in NPC cells following curcumin treatment (Figure $5 \mathrm{~A}$ and $\mathrm{B}$ ). Therefore, curcumin may exert its antitumor activity partly through inhibition of Skp2 and subsequent upregulation of p21 and p57 in NPC cells.

\section{Curcumin increased miR-7 expression in NPC cells}

Emerging evidence has revealed that miR-7 plays a key role in tumorigenesis. To explore whether curcumin could control the expression of miR-7 in NPC cells, miRNA RT-PCR was conducted on RNA isolated from NPC cells following curcumin treatment. As we expected, miR-7 expression was significantly upregulated in curcumin-treated NPC cells (Figure 6A). This observation indicated that curcumin could induce miR-7 expression in NPC cells. To further explore whether curcumin inhibited Skp2 via upregulation 
A

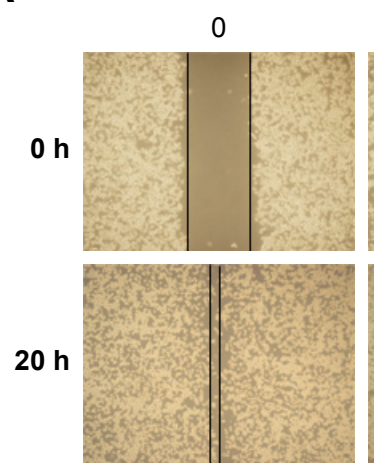

B

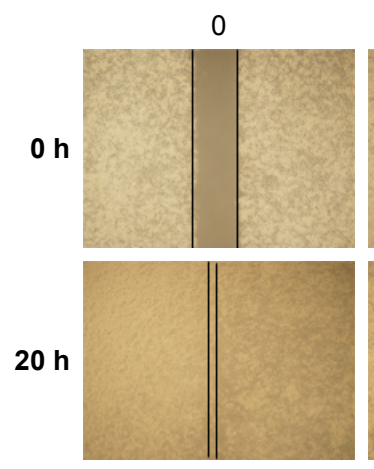

CNE1 cell

5
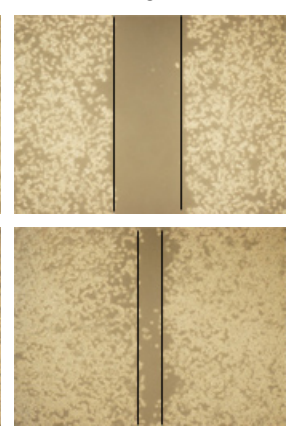

CNE2 cell

10

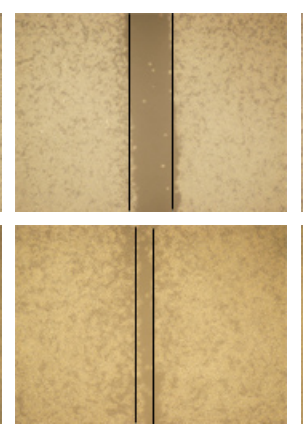

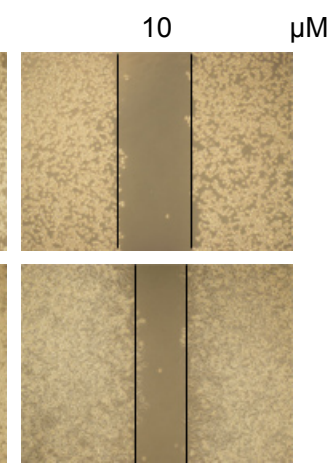

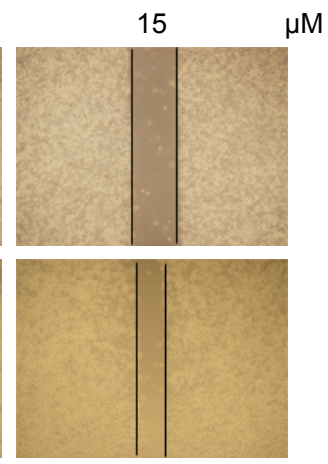

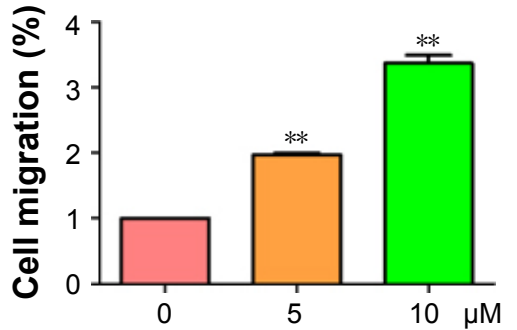

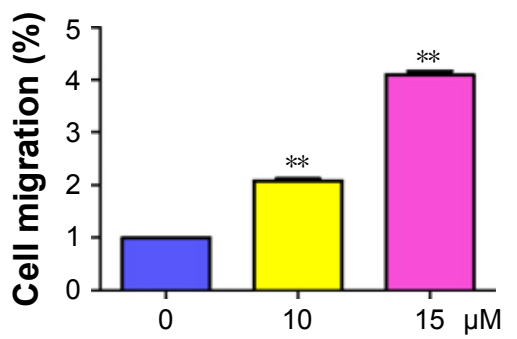

Figure 3 Curcumin inhibited cell migration in NPC cells.

Notes: (A, B) Left panel: the inhibitory effect of curcumin on cell migration was measured using wound healing assay in CNEI (A) and CNE2 (B) cells. Right panel: quantitation of wound healing results. $* * P<0.01$, vs control (DMSO treatment).

Abbreviations: NPC, nasopharyngeal carcinoma; DMSO, dimethyl sulfoxide.

of miR-7, NPC cells were transfected with miR-7 mimics. Transfection of miR-7 mimics in NPC cells inhibited the expression of Skp2 and increased the abundance of $\mathrm{p} 21$ and $\mathrm{p} 57$ (Figure 6B). These results indicated that curcumin could inhibit Skp2 in part, through upregulation of miR-7 in NPC cells.

\section{MiR-7 inhibitor enhanced cell growth in NPC cells}

To further detect the role of miR-7 in cell proliferation, we transfected NPC cells with an miR-7 inhibitor and incubated them for $72 \mathrm{~h}$ prior to measuring cellular proliferation using an MTT assay. We observed that depletion of miR-7 promoted cell proliferation in both CNE1 and CNE2 cells (Figure 7A). Consistently, inhibition of miR-7 partly abrogated cell growth inhibition induced by curcumin treatment (Figure 7A) in NPC cells. We also measured cell invasion in NPC cells following miR-7 inhibitor transfection and curcumin treatment. We observed that inhibition of miR-7 increased cell invasion in NPC cells, and partially rescued curcumin-induced inhibition of cell invasion (Figure 7B). Our protein analysis revealed that miR-7 inhibitor treatment led to elevated Skp2 levels (Figure 7C). These results indicated that curcumin exerted its antitumor effects in part, through upregulation of miR-7 and subsequent inhibition of Skp2 in NPC cells.

\section{Discussion}

Emerging evidence has demonstrated that curcumin exerts anticancer activity in human cancers including NPC. It has been reported that curcumin suppressed the growth of NPC cells through inducing apoptosis. ${ }^{32}$ Moreover, curcumin altered the migratory phenotype of NPC cells via upregulation of E-cadherin. ${ }^{33}$ Furthermore, curcumin induced apoptotic death via the ROS, mitochondrial depolarization, and CASP3-dependent signaling response in NPC cells. ${ }^{34}$ Similarly, treating NPC cells with a new curcumin analog exhibited anticancer function and induced radiosensitivity through inactivation of Jab1. ${ }^{35,36}$ Notably, curcumin was also observed to enhance radiosensitivity through regulation of long non-coding RNAs in NPC. ${ }^{37}$ Additionally, curcumin altered ERK1/2 signaling pathway and regulation of FOXO3a and $\mathrm{p} 53$, leading to inhibition of cell proliferation in NPC cells. ${ }^{38,39}$ In this study, we found that curcumin may also 

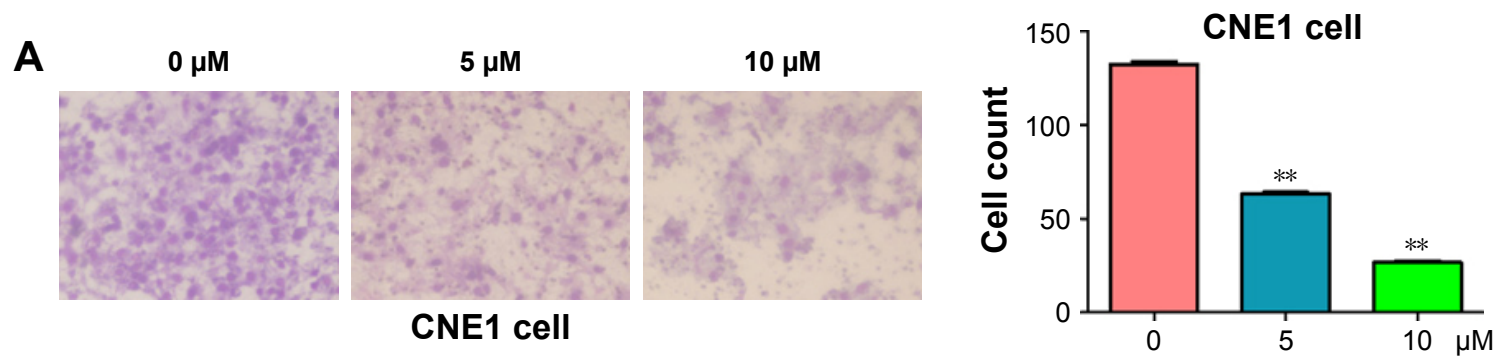

$0 \mu \mathrm{M}$

$10 \mu \mathrm{M}$

$15 \mu \mathrm{M}$
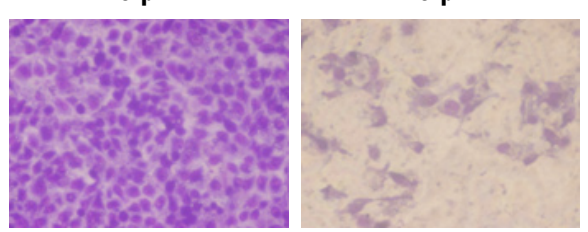

CNE2 cell
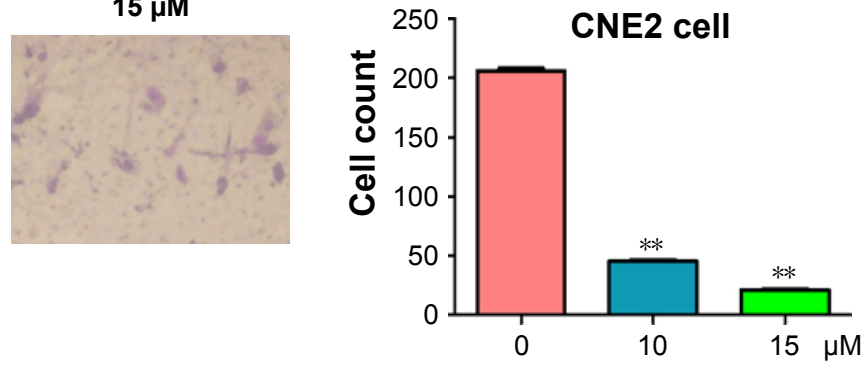

B
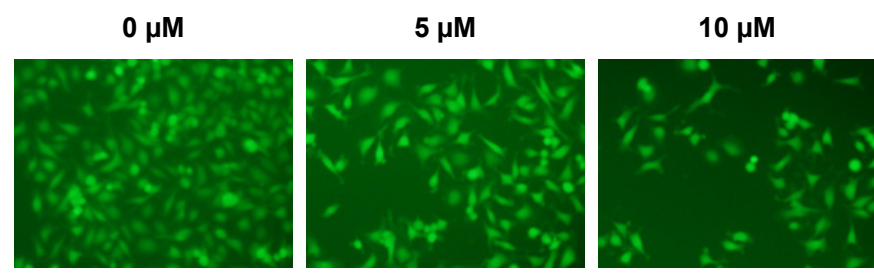

Migration

CNE1 cell

$0 \mu \mathrm{M}$

$10 \mu \mathrm{M}$
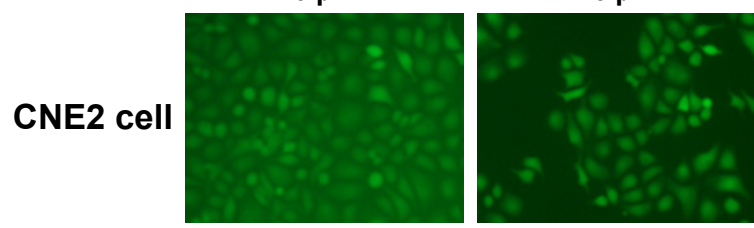

$15 \mu \mathrm{M}$

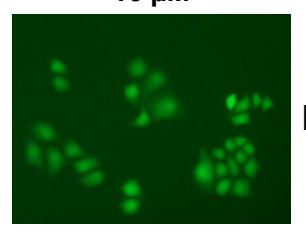

Migration
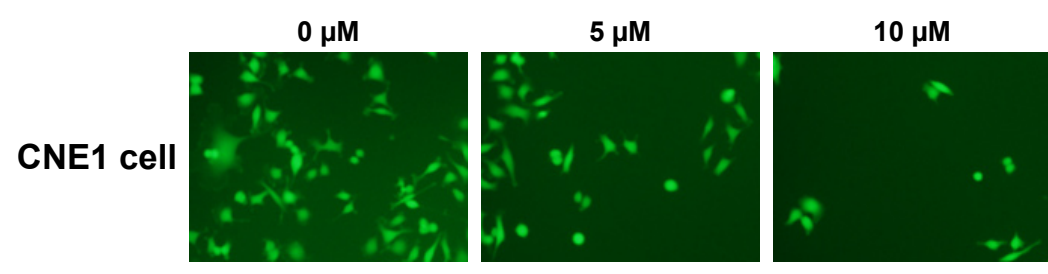

Invasion
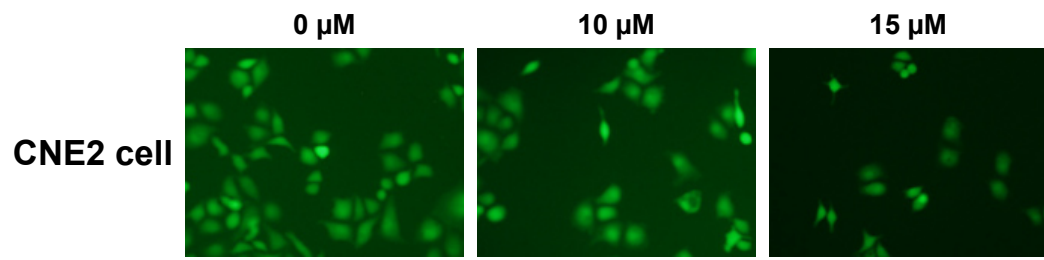

Invasion

Figure 4 Curcumin inhibited cell invasion in NPC cells.

Notes: (A) Left panel: the inhibitory effect of curcumin on NPC cell invasion was assessed using transwell assay. The invaded cells in the membrane were stained with Wright-Giemsa. Right panel: quantitation transwell assay results. $* * P<0.01$ vs control. (B) Transwell assay was performed to measure the cell invasion in NPC cells after curcumin treatment. The invaded cells in the membrane were stained with $4 \mu \mathrm{g} / \mathrm{mL}$ calcein $\mathrm{AM}$ in Hanks' buffered saline at $37^{\circ} \mathrm{C}$ for I h.

Abbreviation: NPC, nasopharyngeal carcinoma.

exert its antitumor activity in part, through suppression of Skp2 in NPC cells.

Recently, miR-7 has been considered as an important regulator in tumorigenesis. Regulation of EGFR and erlotinib sensitivity by miR-7 has been reported in head and neck cancer cells. ${ }^{40}$ It has been shown that overexpression of miR-7 enhanced efficacy of green tea polyphenols due to induction of apoptosis in human malignant neuroblastoma cells. ${ }^{40}$ Moreover, miR-7 inhibited brain metastasis of breast cancer stem-like cells via targeting of KLF4. ${ }^{41} \mathrm{Ma}$ et al 
A

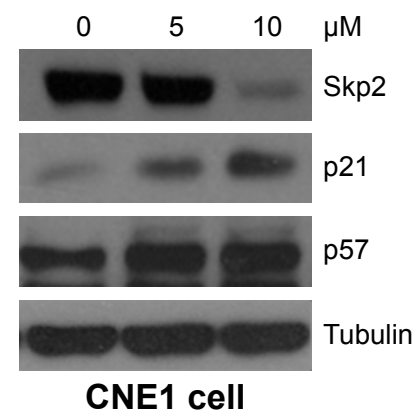

B
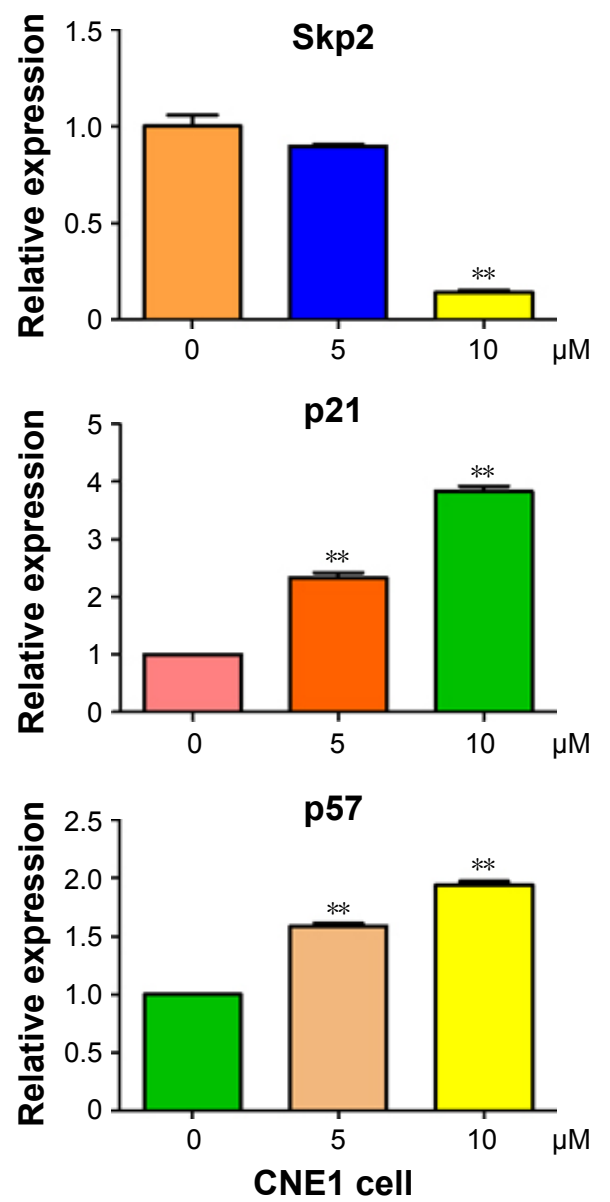

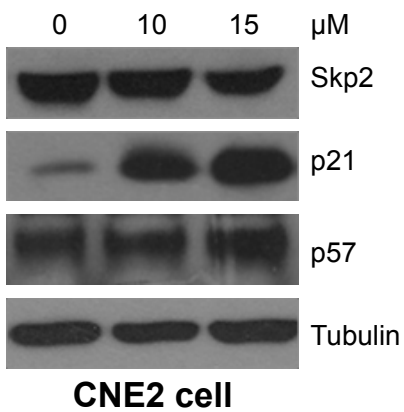

CNE2 cell
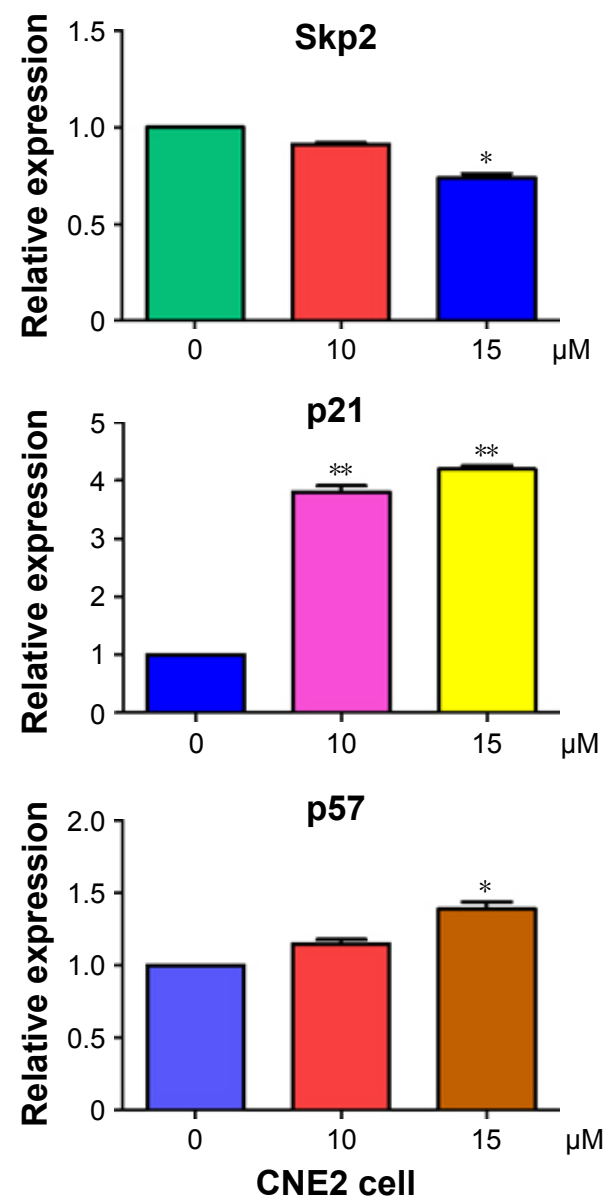

Figure 5 Curcumin inhibited the expression of Skp2 in NPC cells.

Notes: (A) The expression of Skp2, p2I, and p57 was measured in NPC cells following curcumin treatment. (B) Quantitative results are illustrated for panel (A). $* P<0.05$, $* * P<0.0$ l, compared with control.

Abbreviation: NPC, nasopharyngeal carcinoma.

found that down-regulation of miR-7 upregulated CUL5 to facilitate the G1/S transition. ${ }^{42} \mathrm{Xu}$ et al reported that miR-7 suppressed cell proliferation and induced apoptosis via inhibition of XRCC2 in colorectal cancer cells. ${ }^{43}$ Similarly, miR-7 inhibited the invasion and metastasis in part, through suppressing EGFR expression in gastric cancer cells. ${ }^{44}$ Restoration of miR-7 inhibited cell growth via modulation of EGFR signaling in Lewis lung cancer cells..$^{45}$ Furthermore,
miR-7 inhibited cell growth via interference with PI3K/Akt and Raf/MEK/ERK pathways in glioblastoma. ${ }^{46}$ Strikingly, miR-7 inhibited SETDB1 and reversed EMT of breast cancer stem cells through down-regulation of the STAT3 pathway. ${ }^{47}$ It has been identified that $\mathrm{Bcl}-2$ could be one target of miR-7 in serous ovarian carcinomas. ${ }^{48}$ Recently, Liu et al identified that miR-7 modulated chemoresistance through repression of MRP1/ABCC1 in small cell lung cancer. ${ }^{49}$ Notably, systemic 
A
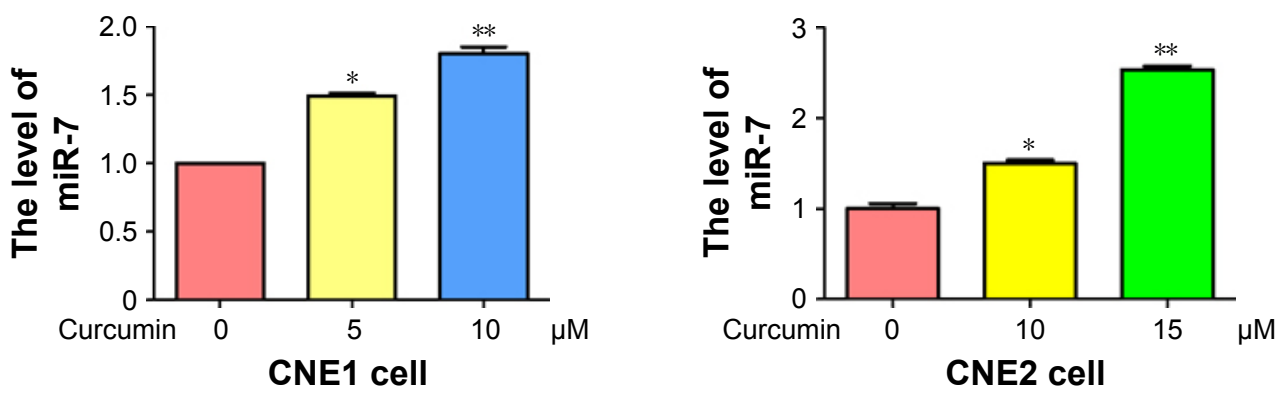

B
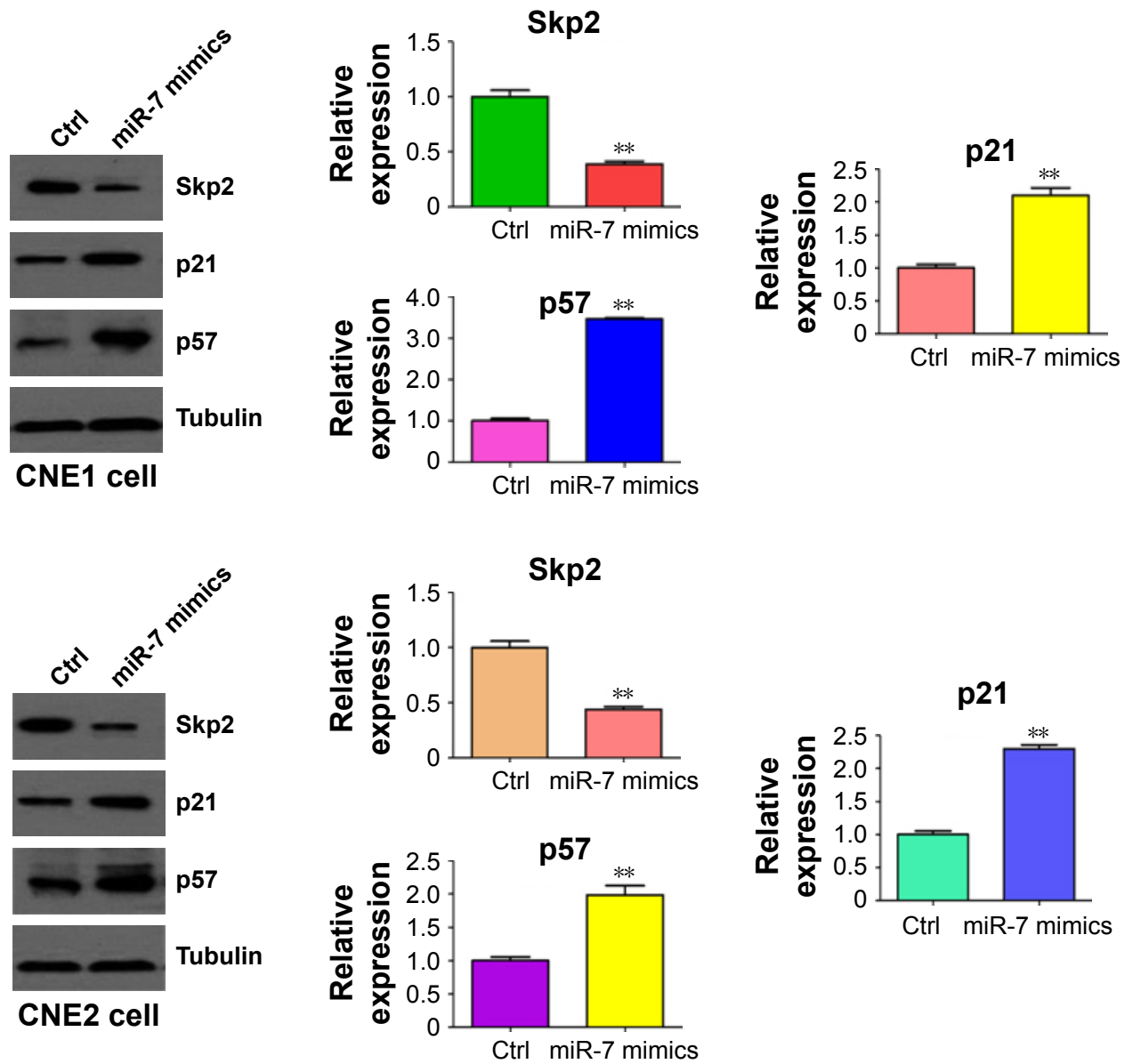

Figure 6 Curcumin upregulated miR-7 level in NPC cells.

Notes: (A) The expression of miR-7 was measured by miRNA real-time RT-PCR in NPC cells following curcumin treatment. (B) Left panel: the expression of Skp2, p2 I, and p57 was measured in NPC cells following transfection of miR-7 mimics. Right panel: quantitation of results in left panel. $* P<0.05$; $* * P<0.01$, compared with control. Abbreviations: NPC, nasopharyngeal carcinoma; RT-PCR, reverse transcription polymerase chain reaction; Ctrl, control.

miR-7 delivery inhibited tumor angiogenesis and growth in a murine xenograft model of glioblastoma. ${ }^{50}$ Interestingly, miR-7 played a critical role in radioresistance of NPC cells to $\mathrm{X}$-ray dose. ${ }^{51}$ Chen et al reported that NPC cells significantly increased the expression of miR-7 after radiation treatment, indicating that suppression of miR-7 expression may enhance the radiosensitivity of NPC cells through upregulation of EGFR expression. ${ }^{51}$ Strikingly, miR-7 triggered cell cycle arrest through inhibition of Skp2 expression in human cancer cells. ${ }^{52}$ Indeed, in our study we also observed that miR-7 overexpression inhibited the expression of Skp2 in NPC cells. More importantly, our findings showed that curcumin increased miR-7 levels in NPC cells. Altogether, our results reveal that curcumin may exert its antitumor activity by increasing miR-7 expression, leading to a subsequent decrease in Skp2 expression in NPC cells. 
A

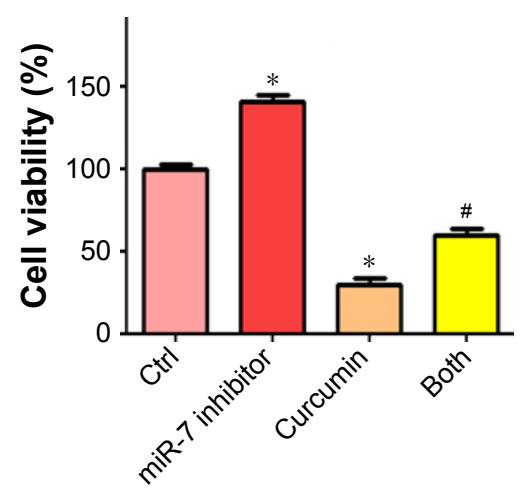

CNE2 cell

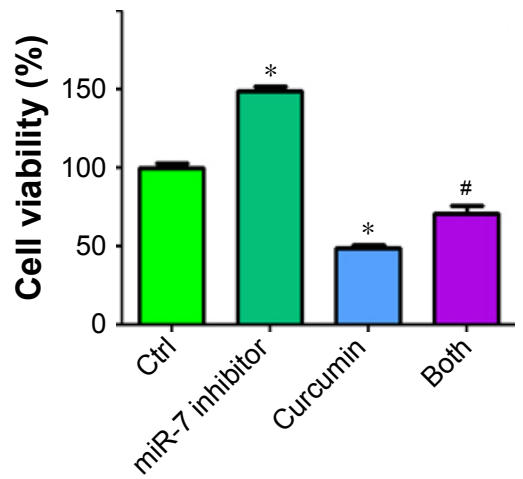

B
Ctrl
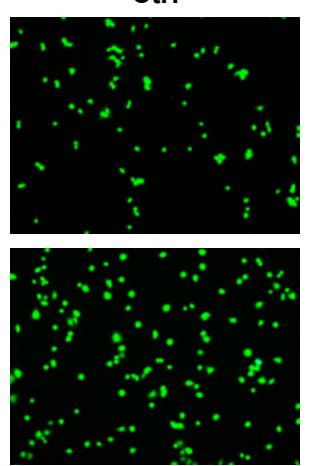

miR-7 inhibitor
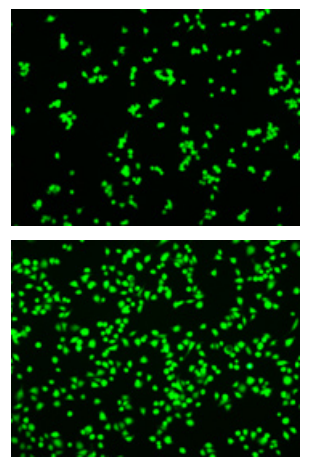

C

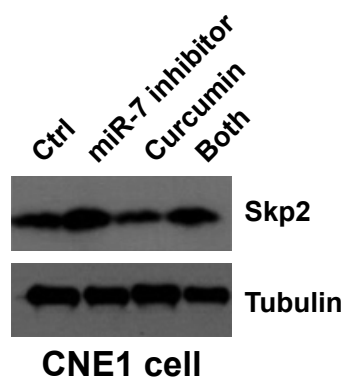

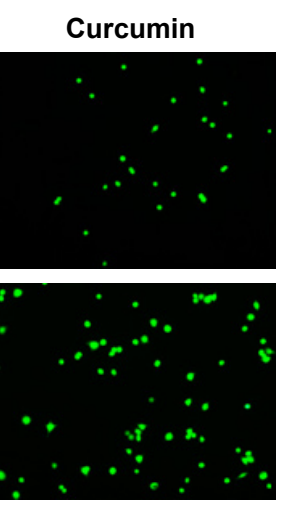

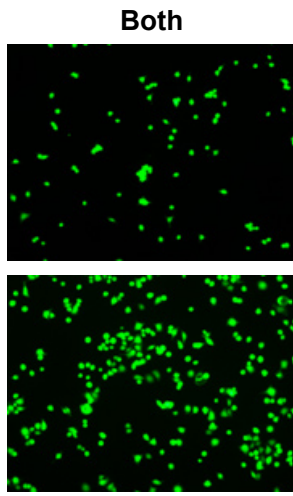

CNE1 cell

CNE2 cell

Figure 7 miR-7 inhibitor enhanced cell growth and invasion in NPC cells.

Notes: (A) MTT assay was performed on NPC cells after curcumin treatment, miR-7 inhibitor transfection, or a combination of both. ${ }^{*} P<0.05$ compared to control; ${ }^{*}<0.05$ compared to curcumin treatment alone or miR-7 inhibitor alone. CNEI cells: $10 \mu \mathrm{M}$ curcumin; CNE2 cells: $15 \mu \mathrm{M}$ curcumin treatment. (B) Cell invasion was measured using transwell inserts with Matrigel in NPC cells after curcumin treatment or miR-7 inhibitor transfection, or a combination of both. (C) The expression of Skp2 was measured in NPC cells after miR-7 inhibitor transfection and curcumin treatment.

Abbreviations: NPC, nasopharyngeal carcinoma; MTT, (3-(4,5-dimethyl-2-thiazolyl)-2,5-diphenyl-2-H-tetrazolium bromide); Ctrl, control.

Skp2 plays an oncogenic role by targeting and degrading its ubiquitination targets such as $21,,^{53} \mathrm{p} 27,{ }^{54} \mathrm{p} 57,{ }^{55}$ E-cadherin, ${ }^{56}$ and FOXO1. ${ }^{57}$ Higher expression of Skp2 is associated with poor prognosis in human cancers including pancreatic cancer, ${ }^{58,59}$ prostate cancer, ${ }^{59}$ breast cancer ${ }^{60,61}$ and glioma. ${ }^{62}$ Wang et al reported that Skp2 expression predicted poor prognosis and maintained the cancer stem cell pool in NPC. ${ }^{63-65}$ Since Skp2 is a key oncoprotein, it is important to identify Skp2 inhibitors for treating human cancers. Several Skp2 inhibitors such as CpdA have been reported to block Skp2 E3 ligase activity ${ }^{66}$ Another Skp2 inhibitor,
SZL-P1-41, was reported to trigger cellular senescence. ${ }^{67}$ Due to the toxic nature of these chemical inhibitors, it is necessary to identify natural agents to target Skp2. In the present study, we validated that curcumin could be a safe agent for inactivation of Skp2 via upregulation of miR-7 in NPC.

\section{Acknowledgment}

This work was supported by a grant from the National Natural Science Foundation of China (NSFC 81572936) and a project funded by the priority academic program development of Jiangsu higher education institutions. 


\section{Disclosure}

The authors report no conflicts of interest in this work.

\section{References}

1. Torre LA, Bray F, Siegel RL, Ferlay J, Lortet-Tieulent J, Jemal A. Global cancer statistics, 2012. CA Cancer J Clin. 2015;65(2):87-108.

2. Dai W, Zheng H, Cheung AK, Lung ML. Genetic and epigenetic landscape of nasopharyngeal carcinoma. Chin Clin Oncol. 2016;5(2):16.

3. Sze H, Blanchard P, Ng WT, Pignon JP, Lee AW. Chemotherapy for nasopharyngeal carcinoma-current recommendation and controversies. Hematol Oncol Clin North Am. 2015;29(6):1107-1122.

4. Chen QY, Wen YF, Guo L, et al. Concurrent chemoradiotherapy vs radiotherapy alone in stage II nasopharyngeal carcinoma: phase III randomized trial. J Natl Cancer Inst. 2011;103(23):1761-1770.

5. Bartel DP. MicroRNAs: target recognition and regulatory functions. Cell. 2009;136(2):215-233.

6. Ambros V. MicroRNA pathways in flies and worms: growth, death, fat, stress, and timing. Cell. 2003;113(6):673-676.

7. Lin S, Gregory RI. MicroRNA biogenesis pathways in cancer. Nat Rev Cancer. 2015;15(6):321-333.

8. Li YJ, Wang CH, Zhou Y, et al. TLR9 signaling repressed tumor suppressor miR-7 expression through up-regulation of HuR in human lung cancer cells. Cancer Cell Int. 2013;13(1):90.

9. Hansen TB, Kjems J, Damgaard CK. Circular RNA and miR-7 in cancer. Cancer Res. 2013;73(18):5609-5612.

10. Zhao J, Wang K, Liao Z, et al. Promoter mutation of tumor suppressor microRNA-7 is associated with poor prognosis of lung cancer. Mol Clin Oncol. 2015;3(6):1329-1336.

11. Horsham JL, Ganda C, Kalinowski FC, Brown RA, Epis MR, Leedman PJ. MicroRNA-7: A miRNA with expanding roles in development and disease. Int J Biochem Cell Biol. 2015;69:215-224.

12. Zhao J, Tao Y, Zhou Y, et al. MicroRNA-7: a promising new target in cancer therapy. Cancer Cell Int. 2015;15:103.

13. Glover AR, Zhao JT, Gill AJ, et al. MicroRNA-7 as a tumor suppressor and novel therapeutic for adrenocortical carcinoma. Oncotarget. 2015;6(34):36675-36688.

14. Yue K, Wang X, Wu Y, Zhou X, He Q, Duan Y. microRNA-7 regulates cell growth, migration and invasion via direct targeting of PAK1 in thyroid cancer. Mol Med Rep. 2016;14(3):2127-2134.

15. Giles KM, Brown RA, Ganda C, et al. microRNA-7-5p inhibits melanoma cell proliferation and metastasis by suppressing RelA/NF-kappaB. Oncotarget. 2016;7(22):31663-31680

16. Zeng CY, Zhan YS, Huang J, Chen YX. MicroRNA-7 suppresses human colon cancer invasion and proliferation by targeting the expression of focal adhesion kinase. Mol Med Rep. 2016;13(2):1297-1303.

17. Zhao JG, Men WF, Tang J. MicroRNA-7 enhances cytotoxicity induced by gefitinib in non-small cell lung cancer via inhibiting the EGFR and IGF1R signalling pathways. Contemp Oncol (Pozn). 2015; 19(3):201-206.

18. He X, Li C, Wu X, Yang G. Docetaxel inhibits the proliferation of nonsmall-cell lung cancer cells via upregulation of microRNA-7 expression. Int J Clin Exp Pathol. 2015;8(8):9072-9080.

19. Dong W, Li B, Wang J, et al. Diagnostic and predictive significance of serum microRNA-7 in esophageal squamous cell carcinoma. Oncol Rep. 2016;35(3):1449-1456.

20. Yu Z, Ni L, Chen D, et al. Identification of miR-7 as an oncogene in renal cell carcinoma. J Mol Histol. 2013;44(6):669-677.

21. Meza-Sosa KF,Perez-Garcia EI, Camacho-Concha N, Lopez-GutierrezO, Pedraza-Alva G, Perez-Martinez L. MiR-7 promotes epithelial cell transformation by targeting the tumor suppressor KLF4. PLoS One. 2014;9(9):e103987.

22. Aggarwal BB, Deb L, Prasad S. Curcumin differs from tetrahydrocurcumin for molecular targets, signaling pathways and cellular responses. Molecules. 2015;20(1):185-205.

23. Kanai M. Therapeutic applications of curcumin for patients with pancreatic cancer. World J Gastroenterol. 2014;20(28):9384-9391.
24. Beevers CS, Zhou H, Huang S. Hitting the golden TORget: curcumin's effects on mTOR signaling. Anticancer Agents Med Chem. 2013;13(7):988-994.

25. Shehzad A, Lee YS. Molecular mechanisms of curcumin action: signal transduction. Biofactors. 2013;39(1):27-36.

26. Momtazi AA, Shahabipour F, Khatibi S, Johnston TP, Pirro M, Sahebkar A. Curcumin as a MicroRNA regulator in cancer: a review. Rev Physiol Biochem Pharmacol. 2016;171:1-38.

27. Yu D, An F, He X, Cao X. Curcumin inhibits the proliferation and invasion of human osteosarcoma cell line MG-63 by regulating miR-138. Int J Clin Exp Pathol. 2015;8(11):14946-14952.

28. Chen J, Xu T, Chen C. The critical roles of miR-21 in anti-cancer effects of curcumin. Ann Transl Med. 2015;3(21):330.

29. Wu H, Liu Q, Cai T, Chen YD, Wang ZF. Induction of microRNA-146a is involved in curcumin-mediated enhancement of temozolomide cytotoxicity against human glioblastoma. Mol Med Rep. 2015;12(4):5461-5466.

30. Gao W, Chan JY, Wong TS. Curcumin exerts inhibitory effects on undifferentiated nasopharyngeal carcinoma by inhibiting the expression of miR-125a-5p. Clin Sci (Lond). 2014;127(9):571-579.

31. Gao JK, Wang LX, Long B, et al. Arsenic trioxide inhibits cell growth and invasion via down-regulation of Skp2 in pancreatic cancer cells. Asian Pac J Cancer Prev. 2015;16(9):3805-3810.

32. Lin YT, Wang LF, Hsu YC. Curcuminoids suppress the growth of pharynx and nasopharyngeal carcinoma cells through induced apoptosis. J Agric Food Chem. 2009;57(9):3765-3770.

33. Wong TS, Chan WS, $\mathrm{Li} \mathrm{CH}$, et al. Curcumin alters the migratory phenotype of nasopharyngeal carcinoma cells through up-regulation of E-cadherin. Anticancer Res. 2010;30(7):2851-2856.

34. Kuo CL, Wu SY, Ip SW, et al. Apoptotic death in curcumin-treated NPC-TW 076 human nasopharyngeal carcinoma cells is mediated through the ROS, mitochondrial depolarization and caspase-3-dependent signaling responses. Int J Oncol. 2011;39(2):319-328.

35. Pan Y, Xiao J, Liang G, et al. A new curcumin analogue exhibits enhanced antitumor activity in nasopharyngeal carcinoma. Oncol Rep. 2013; 30(1):239-245.

36. Pan Y, Wang M, Bu X, et al. Curcumin analogue T83 exhibits potent antitumor activity and induces radiosensitivity through inactivation of Jab1 in nasopharyngeal carcinoma. BMC Cancer. 2013;13:323.

37. Wang Q, Fan H, Liu Y, et al. Curcumin enhances the radiosensitivity in nasopharyngeal carcinoma cells involving the reversal of differentially expressed long non-coding RNAs. Int J Oncol. 2014;44(3):858-864.

38. Xie YQ, Wu XB, Tang SQ. Curcumin treatment alters ERK-1/2 signaling in vitro and inhibits nasopharyngeal carcinoma proliferation in mouse xenografts. Int J Clin Exp Med. 2014;7(1):108-114.

39. Wu J, Tang Q, Zhao S, et al. Extracellular signal-regulated kinase signaling-mediated induction and interaction of FOXO3a and p53 contribute to the inhibition of nasopharyngeal carcinoma cell growth by curcumin. Int J Oncol. 2014;45(1):95-103.

40. Chakrabarti M, Ai W, Banik NL, Ray SK. Overexpression of miR-7-1 increases efficacy of green tea polyphenols for induction of apoptosis in human malignant neuroblastoma SH-SY5Y and SK-N-DZ cells. Neurochem Res. 2013;38(2):420-432.

41. Okuda H, Xing F, Pandey PR, et al. miR-7 suppresses brain metastasis of breast cancer stem-like cells by modulating KLF4. Cancer Res. 2013;73(4):1434-1444.

42. Ma C, Qi Y, Shao L, Liu M, Li X, Tang H. Downregulation of miR-7 upregulates Cullin 5 (CUL5) to facilitate G1/S transition in human hepatocellular carcinoma cells. IUBMB Life. 2013;65(12):1026-1034.

43. Xu K, Chen Z, Qin C, Song X. miR-7 inhibits colorectal cancer cell proliferation and induces apoptosis by targeting XRCC2. Onco Targets Ther. 2014;7:325-332.

44. Xie J, Chen M, Zhou J, et al. miR-7 inhibits the invasion and metastasis of gastric cancer cells by suppressing epidermal growth factor receptor expression. Oncol Rep. 2014;31(4):1715-1722.

45. Li J, Zheng Y, Sun G, Xiong S. Restoration of miR-7 expression suppresses the growth of Lewis lung cancer cells by modulating epidermal growth factor receptor signaling. Oncol Rep. 2014;32(6):2511-2516. 
46. Liu Z, Jiang Z, Huang J, et al. miR-7 inhibits glioblastoma growth by simultaneously interfering with the PI3K/ATK and Raf/MEK/ERK pathways. Int J Oncol. 2014;44(5):1571-1580.

47. Zhang H, Cai K, Wang J, et al. MiR-7, inhibited indirectly by lincRNA HOTAIR, directly inhibits SETDB1 and reverses the EMT of breast cancer stem cells by downregulating the STAT3 pathway. Stem Cells. 2014;32(11):2858-2868.

48. Swiercz A, Chechlinska M, Kupryjanczyk J, et al. miR-7 expression in serous ovarian carcinomas. Anticancer Res. 2015;35(4):2423-2429.

49. Liu H, Wu X, Huang J, Peng J, Guo L. miR-7 modulates chemoresistance of small cell lung cancer by repressing MRP1/ABCC1. Int J Exp Pathol. 2015;96(4):240-247.

50. Babae N, Bourajjaj M, Liu Y, et al. Systemic miRNA-7 delivery inhibits tumor angiogenesis and growth in murine xenograft glioblastoma. Oncotarget. 2014;5(16):6687-6700.

51. Chen ZX, Sun AM, Chen Y, et al. [Effects of radiosensitivity and X-ray dose on miR-7 expression in nasopharyngeal carcinoma]. Nan Fang Yi Ke Da Xие Xие Bao. 2010;30(8):1810-1812, 1816. Chinese.

52. Sanchez N, Gallagher M, Lao N, et al. MiR-7 triggers cell cycle arrest at the G1/S transition by targeting multiple genes including Skp2 and Psme3. PLoS One. 2013;8(6):e65671.

53. Yu ZK, Gervais JL, Zhang H. Human CUL-1 associates with the SKP1/ SKP2 complex and regulates p21(CIP1/WAF1) and cyclin D proteins. Proc Natl Acad Sci US A. 1998;95(19):11324-11329.

54. Tsvetkov LM, Yeh KH, Lee SJ, Sun H, Zhang H. p27(Kip1) ubiquitination and degradation is regulated by the $\mathrm{SCF}(\mathrm{Skp} 2)$ complex through phosphorylated Thr187 in p27. Curr Biol. 1999;9(12):661-664.

55. Kamura T, Hara T, Kotoshiba S, et al. Degradation of p57Kip2 mediated by SCFSkp2-dependent ubiquitylation. Proc Natl Acad Sci USA. 2003;100(18):10231-10236.

56. Inuzuka H, Gao D, Finley LW, et al. Acetylation-dependent regulation of Skp2 function. Cell. 2012;150(1):179-193.

57. Huang H, Regan KM, Wang F, et al. Skp2 inhibits FOXO1 in tumor suppression through ubiquitin-mediated degradation. Proc Natl Acad Sci U S A. 2005;102(5):1649-1654.
58. Einama T, Kagata Y, Tsuda H, et al. High-level Skp2 expression in pancreatic ductal adenocarcinoma: correlation with the extent of lymph node metastasis, higher histological grade, and poorer patient outcome. Pancreas. 2006;32(4):376-381.

59. Wang Z, Gao D, Fukushima H, et al. Skp2: a novel potential therapeutic target for prostate cancer. Biochim Biophys Acta. 2012;1825(1): 11-17.

60. Radke S, Pirkmaier A, Germain D. Differential expression of the F-box proteins Skp2 and Skp2B in breast cancer. Oncogene. 2005;24(21): 3448-3458.

61. Fujita T, Liu W, Doihara H, Date H, Wan Y. Dissection of the APCCdh1-Skp2 cascade in breast cancer. Clin Cancer Res. 2008;14(7): 1966-1975.

62. Wang L, Ye X, Cai X, et al. Curcumin suppresses cell growth and invasion and induces apoptosis by down-regulation of Skp2 pathway in glioma cells. Oncotarget. 2015;6(20):18027-18037.

63. Wang J, Huang Y, Guan Z, et al. E3-ligase Skp2 predicts poor prognosis and maintains cancer stem cell pool in nasopharyngeal carcinoma. Oncotarget. 2014;5(14):5591-5601.

64. Xu HM, Liang Y, Chen Q, et al. Correlation of Skp2 overexpression to prognosis of patients with nasopharyngeal carcinoma from South China. Chin J Cancer. 2011;30(3):204-212.

65. Fang FM, Chien CY, Li CF, Shiu WY, Chen CH, Huang HY. Effect of S-phase kinase-associated protein 2 expression on distant metastasis and survival in nasopharyngeal carcinoma patients. Int J Radiat Oncol Biol Phys. 2009;73(1):202-207.

66. Chen Q, Xie W, Kuhn DJ, et al. Targeting the p27 E3 ligase SCF(Skp2) results in p27- and Skp2-mediated cell-cycle arrest and activation of autophagy. Blood. 2008;111(9):4690-4699.

67. Chan CH, Morrow JK, Li CF, et al. Pharmacological inactivation of Skp2 SCF ubiquitin ligase restricts cancer stem cell traits and cancer progression. Cell. 2013;154(3):556-568.
OncoTargets and Therapy

\section{Publish your work in this journal}

OncoTargets and Therapy is an international, peer-reviewed, open access journal focusing on the pathological basis of all cancers, potential targets for therapy and treatment protocols employed to improve the management of cancer patients. The journal also focuses on the impact of management programs and new therapeutic agents and protocols on

\section{Dovepress}

patient perspectives such as quality of life, adherence and satisfaction The manuscript management system is completely online and includes a very quick and fair peer-review system, which is all easy to use. Visit http://www.dovepress.com/testimonials.php to read real quotes from published authors. 